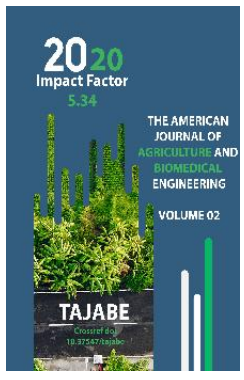

Copyright: Original content from this work may be used under the terms of the creative commons attributes 4.0 licence.

\section{Bioecological Properties Of Helianthus Tuberosus In Introduction Conditions}

\author{
Begmatov Abdusamat Mamatkulovich \\ Associate Professor, Candidate Of Biological Sciences, Termez State University, Head Of The \\ Department Of Botany, Uzbekistan
}

Rakhmatova Masuma Umarovna, Teacher Of The Department Of Zoology, Termez State University, Uzbekistan

\title{
ABSTRACT
}

Bio ecological features of helianthus tuberoses in soil-climatic conditions of Surkhandarya region were studied. The research obtained data on flowering phenology and flowering period under the conditions of introduction, the germination of plant seeds was determined.

\section{KEYWORDS}

Helianthus tuberosus, perspective culture,introduction, flowering period, seed biology, seed germination.

\section{INTRODUCTION}

The introduction of medicinal plants - not only reduces the cost of imported raw materials, but also enriches the biodiversity of our local environment - and partially meets the demand of the population for medicinal plants [2].

One of the important tasks of botany is to study new high-yielding, potentially highyielding crops, assess their nutritional value, create biologically compatible high-quality crops, provide the population with dietary food, nutritious, high-quality food.

The flowering and seed formation of introducers in new conditions is an important indicator of adaptation [3]. Only when the plant's demand for environmental factors adapts to the new conditions does the plant bloom, produce seeds, and eventually leave offspring. This has been reflected in many scientific studies [4]. 
Surkhandarya region is located in the most southern part of the country. It is also located in the southern part of Central Asia, its territory corresponds to the arid subtropical climate zone. The territory of the region is crossed by $37^{\circ} 101-39^{\circ} 021$ north latitude and $66^{\circ} 321-68^{\circ} 251$ east longitude lines [5].

The remote (at the same time southern geographical) location of Surkhandarya region required that it be bordered by more foreign countries than other regions. It is bordered by Tajikistan to the north, northeast and east, Turkmenistan to the west, and the far-flung foreign country to Afghanistan to the south via the Amudarya River. The region is also bordered on the west by high mountains to the Kashkadarya region of the country.

To study the dynamics of diurnal and seasonal flowering, A.N. Ponomarev [6], O.A. Ashurmetov and H.Q. It was carried out on the instructions of Karshibaevs [1]. In the study of the rhythm of daily flowering, 10 identified generative branches were counted flowers that opened every 2 hours from 8 am to $6 \mathrm{pm}$.

Helianthus tuberosus is one of the most important crops in the world, widely used in agriculture, as a raw material for the food, feed, pharmaceutical, cellulose-papercardboard industries. It is native to North America and is still found in wild forms. This crop was brought from North America to Europe after the discovery of the American continent. In Europe, Helianthus tuberosusbegan to spread very quickly. Currently, this crop is very common, especially in France, Hungary, Poland, Scandinavia.

Helianthus tuberosusis one of the plants that has great potential in food, dietary cooking, food cultivation. The main crop of Helianthus tuberosusare the aboveground parts - stems, leaves and the ends of the underground part. In Uzbekistan and abroad, Jerusalem artichoke is grown as a perennial crop and yields 850-1000 quintals of green mass per hectare, 280-400 quintals of green mass, of which 1 quintal of green mass is 24.1; At the end of 30 food units, $80-90 \mathrm{~g}$ of digestible protein is stored in each food unit. The finish is well kept. They contain $11.7 \%$ inulin and $2 \%$ protein.

\section{MATERIALS AND METHODS}

Helianthus tuberosusis also used as a technical crop to obtain fructose by hydrolysis of inulin in its stems. Ethyl alcohol, wine and wine vinegar, food yeasts, beer and other products are also extracted from the waste.

In Western European countries, Helianthus tuberosus are used as a food like potatoes. In cattle raising, the green mass and finish of Helianthus tuberosus is a good food. Its stems and leaves are rich in vitamins, the amount of dry matter reaches $25-30 \%$. It is high in digestible carbohydrates and low in fiber. According to a number of studies, the amount of riboflavin in the green mass of Helianthus tuberosus was $1.75 \mathrm{mg} / \mathrm{kg}$, at the end of 1.9 $\mathrm{mg} / \mathrm{kg}$ nicotinic acid was 8.3 and $18.8 \mathrm{mg} / \mathrm{kg}$, respectively. Its green mass is also rich in $B$ vitamins [8].

In members of the Asteraceae family, the general order of the flower opening sequence is centrifugal. In the conditions of Surkhandarya region, flowering of Helianthus tuberosus was observed 3-4 flowers in a basket in a row or at the same time. The flowering period of a plant depends on its origin, biological properties, the early or late arrival of the spring season, the duration of flowering depends on the weather conditions and agrotechnical measures of the area where the plant grows. As can be seen from the table below, the onset of flowering in Helianthus tuberosus usually occurs in September. Mass flowering is observed on the plant in 30-35 days after flowering.

-table 


\section{Flowering phenology of Helianthus tuberosus(Observed in 10 plants)}

\begin{tabular}{|c|c|c|c|c|c|}
\hline Observed & the & \multicolumn{4}{|c|}{ Flowering period } \\
\cline { 4 - 6 } year & $\begin{array}{c}\text { beginning } \\
\text { of budding }\end{array}$ & $\begin{array}{c}\text { The } \\
\text { beginning } \\
\text { of flowering }\end{array}$ & mass flowering & $\begin{array}{c}\text { The ending of } \\
\text { flowering }\end{array}$ & $\begin{array}{c}\text { duration } \\
\text { (days) }\end{array}$ \\
\hline 2019 & 20.08. & 10.09. & 20.09. & 15.10. & 45 \\
\hline
\end{tabular}

The flowering period lasted 30-35 days, and mass flowering occurred mainly in the second decade of September.

Under the influence of rain and snow in December, the air temperature drops (to +5 , $5^{\circ} \mathrm{C}$ ), resulting in cases of frost damage to flowers. Studies have shown that a single flower of Helianthus tuberosus blooms for 3-4 days, all flowers in a basket for 14-17 days, a generative stem and a plant for 40-45 days. The duration of flowering in Helianthus tuberosus depends on weather conditions, as well as the fact that the air temperature in December 2019 was slightly warmer, with 8$12^{\circ} \mathrm{C}$ during the day.

Seed germination of Helianthus tuberosus plant.Helianthus tuberosus according to the demand for light - a short-day plant. Reducing the length of the light day by 9-10 hours lasts 20-25 days, accelerates flowering by $1.5-2$ hours. Under introduction conditions, it is recommended to take seeds in fields sown in late autumn in the plain zone to obtain the seed yield of Helianthus tuberosus. The development of the Helianthus tuberosus plant is observed until the low temperatures of autumn are observed. In autumn, plant seeds grown in Termez were harvested. At different times, the seeds were stored in paper bags at room temperature and germination was determined.In December, the seeds, stored for 1 month, were sown on a Petri dish in room conditions. According to the study, seed germination was $97 \%$. In seeds stored for two months, the rate was $95 \%$ and in three months it was $93 \%$. Hence, it was confirmed that the germination rates of Helianthus tuberosus seeds are much higher.

\section{CONCLUSIONS}

1. In Surkhandarya region helianthus tuberosus goes through all stages of ontogeny. Due to the onset and duration of budding, flowering and fruiting are observed simultaneously on the scale of the bush.

2. For Helianthus tuberosus, the daytime flowering type is characteristic (8 to 18), the peak of flowering was detected at 12 p.m. At 6 p.m., flowering ended under the influence of a drop in air temperature.

3. The success of the introduction of Helianthus tuberosus was rated at 80 points, which made it possible to calculate a very promising turdeb in Termez conditions.

\section{REFERENCES}


1. Ashurmetov O.A., Karshibaev X.K. "Reproductive biology of licorice and raspberry”. - Tashkent, Science, 1995 .-$212 \mathrm{p}$.

2. Begmatov A.M., Raxmatova M.U. "Bioecological features of Glycyrrhiza L." // Modern research and development, no. 3 (20). Moscow, 2018. -S. 110-113.

3. Begmatov A.M., Sharipov A.E., RakhmatovaM.He"Bioecological features of Stevia rebianaianaBertoni in the conditions of the surkhandarya region"/l integration of fundamental science and practice: problems and prospects materials of the Republican scientificpractical conference. - Tashkent, 2018.

4. Begmatov A. M., Sattarov A.S. "Bioecological properties of Stevia rebaudianaBertoni in introduction conditions". The American Journal of Agriculture and Boimedical Engineering. Volume 2 Issue 10, 2020. -P. 63-68.

5. Sattarov A.S., Begmatov A. M. "Bioecology of melissaofficinalis plant In Introduction conditions". The American Journal of Agriculture and Boimedical Engineering. Volume 2 Issue 10, 2020. -P. 69-73.

6. Ponomarev A.N. "Study of flowering and pollination of plants" / Field geobotany. In 5 volumes - M.-L .: AN SSSR, 1960. T. 2. P. 9-19.

7. Rakhmatullaev A. "Creating a starting material for Helianthus tuberosus selection". Master's degree dissertation. Samarkand, 2013.-97 p.

8. Umirzaqova Z.I., Sharipova G. "Prospects for the use of Helianthus tuberosus (Helianthus tuberoses L) as a food plant for livestock". Scientific achievements and prospects for agricultural development. Proceedings of the scientific conference of SamSU. 2005 y. B. $79-80$. 